\title{
Effects of nurse-plant canopy light intensity on shrub seedling growth
}

\author{
TIMOTHY E. FULBRIGHT, JOSEPH O. KUTI, AND ALAN R. TIPTON
}

Authors are professor, Caesar Kleberg Wildlife Research Institute, Box 218, Texas A\&M University-Kingsville, Kingsville, Tex. 78363; associate professor, Dept. of Agronomy and Resource Sciences, Texas A\&M University-Kingsville, Kingsville, Tex. 78363; and director, Office of Institutional Research, Texas A\&M University-Kingsville, Kingsville, Tex. 78363.

\section{Abstract}

Spiny hackberry (Celtis pallida Torr.) occurs almost exclusively beneath honey mesquite (Prosopis glandulosa Torr.) canopies. We hypothesized that maximum early seedling growth of spiny hackberry occurs at light intensities similar to those beneath honey mesquite, whereas maximum growth of huisache (Acacia smallii Isely), a plant characteristic of nonshaded habitats, occurs at light intensities near full sunlight. Photosynthetic photon flux densities (PPFD) under 4 honey mesquite canopies and in adjacent interspaces were recorded during July 1990 to July 1992. Seedling growth indices of spiny hackberry and huisache were determined at PPFDs characteristic of those found under honey mesquite canopies and in herbaceous interspaces. In contrast to our prediction, relative growth rate $\left(K_{w}\right)$, net assimilation rate (NAR), and seedling mass of spiny hackberry were greater in sunlight than in shade characteristic of honey mesquite canopies. Huisache also had greater $K_{w}$, NAR, and total seedling mass in sunlight. Aggregation of spiny hackberry beneath honey mesquite canopies does not result from an ability to maintain maximum seedling growth at low light intensities.

Key Words: Acacia smallii, Celtis pallida, facilitation, growth analysis, honey mesquite, huisache, Prosopis glandulosa, relative growth rate, spiny hackberry

Woody plant succession in upland grasslands in southern Texas occurs in part through initial colonization by honey mesquite (Prosopis glandulosa Torr.) followed by establishment of subordinate shrubs, including spiny hackberry (Celtis pallida Torr.). Spiny hackberry occurs primarily beneath honey mesquite canopies and is absent from herb-dominated interspaces between canopies (Archer et al. 1988, Franco-Pizaña et al. 1995). In contrast to spiny hackberry, huisache (Acacia smallii Isely) is an early-successional heliophyte characteristic of open habitats and does not occur under the canopy of other shrubs (Bush and Van Auken 1986, Archer et al. 1988).

The authors thank C. Coldiron, J. Franco-Pizaña, J. Perez, Jr., and S. Siekenius for assistance in data collection and programming of microloggers, and $R$. Bingham for assistance in data analyses. Research was funded by USDA, CSRS Rangeland Research Grants Program, project number 89-38300-4479; the Caesar Kleberg Foundation for Wildlife Conservation; and the Texas A\&M UniversityKingsville Faculty Research Enhancement Program, Kingsville, Tex.

Manuscript accepted 22 Dec. 1996.
Resúmen

El granjeño espinoso (Celtis pallida Torr.) ocurre casi exclusivamente bajo los baldaquines del mesquite de miel (Prosopis glandulosa Torr.). Nuestra hipótesis es que el crecimiento máximo de la planta temprana del granjeño espinoso ocurre a intensidades de luz similares a ésas que se encuentran bajo el mesquite de miel, mientras que el crecimiento máximo del huisache (Acacia smallii Isely), una planta característica de los habitats sin sombra, ocurre a intensidades de luz muy parecidas a la luz solar. Densidades fotosintéticas de flujo (PPFD) abajo de 4 baldaquines de mesquite de miel y en los interespacios adyacentes fueron registrados durante el período de Julio de 1990 a Julio de 1992. Los índices de crecimiento de el granjeño espinos y del huisache fueron determinados a los PPFDs característicos de ésos encontrados bajo los badalquines del mesquite espinoso y en los interespacios herbáceos. En contraste con nuestra predicción, la tasa relativa de crecimiento $\left(K_{w}\right)$, la tasa neta de asimilación (NAR), y la masa de las plantas del granjeño espinoso fueron mayores en condiciones de luz que bajo las condiciones de sombra características de los baldaquines del mesquite de miel. El huisache también tuvo mayores $K_{w}$, NAR, y masa total de planta bajo la luz del sol. La agregación del granjeño espinoso bajo los baldaquines del mesquite de miel no es el resultado de una abilidad para mantener el crecimiento máximo de las plantas a bajas intensidades de luz.

Photosynthetic responses of sciophytes, plants native to shaded habitats, are typically saturated at lower irradiances than heliophytes, or sun plants (Salisbury and Ross 1985). Sugar hackberry (Celtis laevigata Willd.) occurs in shaded habitats and is a climax forest dominant in flood plain habitats in southern Texas. Bush and van Auken (1986) found that sugar hackberry seedlings maintained maximum growth at low light intensities (403 \pm 117 $\mu \mathrm{mol} \cdot \mathrm{m}^{-2} \cdot \mathrm{s}^{-1}, \bar{x} \pm \mathrm{SD}$ ), which allows the plant to occupy shaded habitats and exploit the greater soil nutrients beneath forest canopies. The almost exclusive presence of spiny hackberry beneath honey mesquite could in part be explained if seedling growth of this shrub has a similar photosynthetic response to sugar hackberry.

Our first objective was to characterize photosynthetic photon flux densities (PPFD) beneath honey mesquite and in adjacent herb-dominated interspaces. We hypothesized that maximum 
early seedling growth of spiny hackberry occurs at light intensities similar to those beneath honey mesquite and that maximum growth of huisache occurs at light intensities near full sunlight. To test our hypothesis, our second objective was to evaluate that relative growth rate $\left(\mathrm{K}_{\mathrm{w}}\right)$, net assimilation rate (NAR), and other seedling growth indices of spiny hackberry and huisache differ under different light intensities.

\section{Materials and Methods}

\section{Photosynthetic Photon Flux Density}

Photosynthetic photon flux density beneath honey mesquite canopies and in interspaces were measured from July 1990 to July 1992 at the Texas A\&M-Kingsville University Range and Wildlife Research Area $15 \mathrm{~km}$ south of Kingsville, Texas $\left(27^{\circ}\right.$ $36^{\prime} \mathrm{N}, 97^{\circ} 57^{\prime} \mathrm{W}$ ) with a LI-COR 190SA quantum sensor placed $15 \mathrm{~cm}$ above ground level under each of 4 randomly selected honey mesquite canopies. A quantum sensor was also placed in each of 4 adjacent herb-dominated interspaces between honey mesquite canopies. Quantum sensors were placed in a randomly selected direction about $0.5 \mathrm{~m}$ away from the trunk of honey mesquite trees where the only overhead canopy was honey mesquite. Spiny hackberry density was greatest $0.5 \mathrm{~m}$ from honey mesquite trunks and spatial distribution of the shrub was not directionally oriented (Franco-Pizaña et al. 1995). A Campbell Scientific $21 \mathrm{X}$ datalogger was programmed to record PPFD every 10 minutes, and then average and store the values every $30 \mathrm{~min}$ utes. Mean monthly maximum PPFD (the average half-hour mean maximum PPFD in a month across replications) and mean daily maximum PPFD in a month across replications) and mean daily maximum PPFD (the average of $n$ half-hour mean maximum PPFDs in a month with $n$ days) in interspaces and under honey mesquite canopies were calculated.

\section{Shrub Seedling Growth}

Effects of shading on seedling growth of spiny hackberry and huisache were determined in the field during late May to late July 1991 with shaded and unshaded wooden structures. The experimental design was a split-plot with PPFD (shade or no shade) as whole plots and plant species as sub-plots. Three pairs (blocks) of wooden frames were partially covered with Nutri gro-3 greenhouse plastic film $(6 \mathrm{mil})$. Shade treatments that simulated mean PPFD under honey mesquite canopies were imposed when the first true leaves were exerted on both species (15-20 days after planting spiny hackberry) by covering 1 randomly selected wooden frame in each pair with shade cloth that reduced incoming sunlight by about $70 \%$. In PPFD measurements beneath mesquite canopies, mean daily maximum PPFD was $71 \%$ lower than in interspaces during May-July 1991.

Photosynthetic photon flux densities in shade and sunlight treatments were measured weekly at midday with a Li-COR 185B photometer and an integrating quantum sensor. The readings were taken at pot height at 10 systematically selected, evenly spaced locations within each treatment. Mean ( \pm SE) PPFD under the plastic film on unshaded wooden structures was $1,893 \pm 4$ $\mu \mathrm{mol} \cdot \mathrm{m}^{-2} \cdot \mathrm{s}^{-1}(n=18,6$ weekly measurements $\times 3$ structures $)$ and PPFD under the shade cloth on shaded wooden frames was $569 \pm$ $4 \mu \mathrm{mol} \cdot \mathrm{m}^{-2} \cdot \mathrm{s}^{-1}(n=18)$.

Five kg of growth medium consisting of 1 part soil; 1 part perlite; 1 part vermiculite; 2 parts sphagnum peat moss (by volume), amended with $13.5 \mathrm{~g}$ of Peters 20-20-20 (W.R. Grace, Fogelsville, Penn.) general purpose fertilizer per $\mathrm{kg}$ of medium mix was placed in $20-\mathrm{cm}$-diameter $\times 38-\mathrm{cm}$-deep plastic pots. The soil was Willacy fine sandy loam harvested from the upper $15 \mathrm{~cm}$ of the profile from a cultivated field. Twenty-four hours before planting, the pots were irrigated with 4 liters of distilled water and allowed to equilibrate. Pots were subirrigated to maintain water content at 80 to $90 \%$ of field capacity during the experiment.

Twenty evenly spaced spiny hackberry seeds were planted in each of 96 pots at a depth of $1 \mathrm{~cm}$. Huisache seeds were planted and pots allocated in the same manner 4 days after spiny hackberry so that the seeds would all germinate at a similar time. Thirty-two pots of each species were randomly assigned to each block.

Temperatures during the experiment were measured weekly with maximum-minimum thermometers placed at pot height in the center of each structure. The mean weekly minimum temperature was $23 \pm 0.2^{\circ} \mathrm{C}(n=36,6$ weekly measurements $\times 6$ structures). Mean weekly maximum temperatures were $49 \pm 1^{\circ} \mathrm{C}(n=$ 18,6 weekly measurements $\times 3$ structures) in the unshaded structures and $39 \pm 1{ }^{\circ} \mathrm{C}(n=18)$ in the shaded structures.

Two randomly selected pots of each species were taken from each structure and 2 seedlings/pot were harvested immediately before the shade treatment was imposed. One week after shade treatments were imposed, following the second harvest, all seedlings were thinned to 2 per pot. Harvests were conducted weekly for a total of 7 harvests and consisted of randomly selecting 2 pots of each species from each treatment. Leaf area was measured with a Decagon digital image analysis system, Version 1.02 (Decagon Devices, Inc., Pullman, Wash.), to the nearest 0.01 $\mathrm{mm}^{2}$. Soil was removed from each pot, placed on a screen, and carefully washed from seedling roots with a fine spray of water. The roots and stems were separated and roots, stems, and leaves were oven-dried at $60^{\circ} \mathrm{C}$ for 48 hours and weighed. After each harvest, all pots were rerandomized within each structure. Ten $\mathrm{ml}$ 8-16-8 liquid fertilizer dissolved in 3.785 liters of distilled water were added at a rate of $500 \mathrm{ml}$ per pot every other week beginning with the second week.

Data obtained from the 7 harvests were used to calculate the following seedling growth indices: relative leaf area expansion rate $\left(K_{\mathrm{a}}\right)$, relative leaf mass expansion rate $\left(\mathrm{K}_{\mathrm{l}}\right)$, relative root mass expansion rate $\left(\mathrm{K}_{\mathrm{r}}\right), \mathrm{K}_{\mathrm{w}}$, leaf area partitioning coefficient (LAP), leaf mass partitioning coefficient (LMP), and NAR (Potter and Jones 1977, Fulbright et al. 1985) (Table 1). form

Seedling growth indices were calculated with equations of the

$$
W=w_{o} e^{k_{w} t}
$$

where $\mathrm{W}$ is total seedling mass, $\mathrm{W}_{\mathrm{o}}$ is initial seedling mass ( $\mathrm{g}$ ), $\mathrm{K}_{\mathrm{w}}$ is relative growth rate, and $t$ is time (weeks). The same equation was used in calculating $K_{a}, K_{l}$, and $K_{r}$, substituting other parameters for $W$. The value of $t$ in calculating NAR, LAP, and LMP was 4 weeks after the initial harvest.

Values used in analyses for each species, PPFD treatment, and block (replication) combination for each harvest were the means of the 4 seedlings within a block. Seedling mass means for the initial harvest were compared with analysis of variance (Cody and Smith 1991). Seedling growth trait means for PPFD treatments were compared with paired t-tests. Means were considered significantly different if $P \leq 0.10$. 
Table 1. Definitions of indices used to describe seedling growth of spiny hackberry and huisache. Adapted from Fulbright et al. (1985).

\begin{tabular}{lc}
\hline \hline Seedling growth trait & Definitions \\
\hline $\mathrm{K}_{\mathrm{a}}$, relative leaf area expansion rate & $\frac{d A / d t}{A}$ \\
$\mathrm{~K}_{\mathrm{l}}$, relative leaf mass expansion rate & $\frac{d L / d t}{L}$ \\
$\mathrm{~K}_{\mathrm{T}}$, relative root mass expansion rate & $\frac{d R / d t}{R}$ \\
$\mathrm{~K}_{\mathrm{W}}$, relative growth rate & $\frac{d W / d t}{W}$ \\
LAP, leaf area partitioning coefficient ${ }^{2}$ & $\frac{d A / d t}{d W / d t}$ \\
LMP, leaf mass partitioning coefficient & $\frac{d L / d t}{d W / d t}$ \\
NAR, net assimilation rate & 2 \\
\end{tabular}

${ }^{1}$ The following abbreviations were used: time $(t)$, seedling leaf area $(A)$, leaf mass (W), root mass ( $R$ ), seedling mass (W), rate of change in seedling leaf area $(d A / d t)$, rate of change in seedling leaf mass $(d L / d t)$, rate of change in seedling root mass $(d R / d t)$, rate of change in seedling mass $(d W / d t)$.

\section{Results}

Light intensity beneath mesquites varied seasonally and was greatest during February or March, when mesquite was partially or totally defoliated (Fig. 1). Lowest light intensities beneath mesquite occurred during April and May and October, December, or January. Mean monthly maximum and mean daily maximum PPFD under canopies ranged from $622 \pm 178$ and $225 \pm 60$ $\mu \mathrm{mol} \cdot \mathrm{m}^{-2} \cdot \mathrm{s}^{-1}$ during April 1992 to $1,444 \pm 48$ and $876 \pm 143$ $\mu \mathrm{mol} \cdot \mathrm{m}^{-2} \cdot \mathrm{s}^{-1}$ during October 1990 . In interspaces, mean monthly maximum and mean daily maximum PPFD ranged from 1,111 \pm 64 and $579 \pm 54 \mu \mathrm{mol} \cdot \mathrm{m}^{-2} \cdot \mathrm{s}^{-1}$ during December 1991 to $2,419 \pm$ 49 during June 1991 and $2,011 \pm 11 \mu \mathrm{mol} \cdot \mathrm{m}^{-2} \cdot \mathrm{s}^{-1}$ during August 1990.

Data for each shrub species were analyzed separately because initial seedling mass of huisache $(0.1 \pm 0.01 \mathrm{~g})$ exceeded $(P \leq 0.10)$ spiny hackberry $(0.02 \pm 0.004 \mathrm{~g})$. Initial seedling mass, averaged across shrub species, could not be distinguished $(P>0.10)$ between interspace PPFD $(0.06 \pm 0.03)$ and canopy PPFD $(0.06 \pm 0.03)$.

Relative leaf mass expansion rate, $K_{r}, K_{w}$, NAR, leaf area, leaf mass, root mass, stem mass, and total mass of spiny hackberry seedlings were greater $(P \leq 0.10)$ in unshaded than in shaded treatments (Table 2). Leaf area of spiny hackberry more than doubled in sunlight compared to shade, whereas huisache leaf area did not differ $(P=>0.10)$ between the 2 treatments. Huisache had greater $(P \leq 0.10) \mathrm{K}_{\mathrm{r}}, \mathrm{K}_{\mathrm{w}}$, NAR, leaf mass, root mass, stem mass, and seedling mass in interspace PPFD, as predicted.

For both species, LAP and LMP were greater $(P \leq 0.10)$ in canopy PPFD than in interspace PPFD. Relative growth rate of spiny hackberry and huisache was positively correlated with NAR $(0.91, P \leq 0.10$ and $0.89, P \leq 0.10$, respectively) and negatively correlated with LAP $(-0.90, P \leq 0.10$ and $-0.82, P \leq 0.10$, respectively).

\section{Discussion}

Presence of spiny hackberry beneath honey mesquite apparently does not result from ability of the shrub to maintain maximum seedling growth at low light intensities. Possible factors underlying presence of spiny hackberry beneath mesquite that we did not

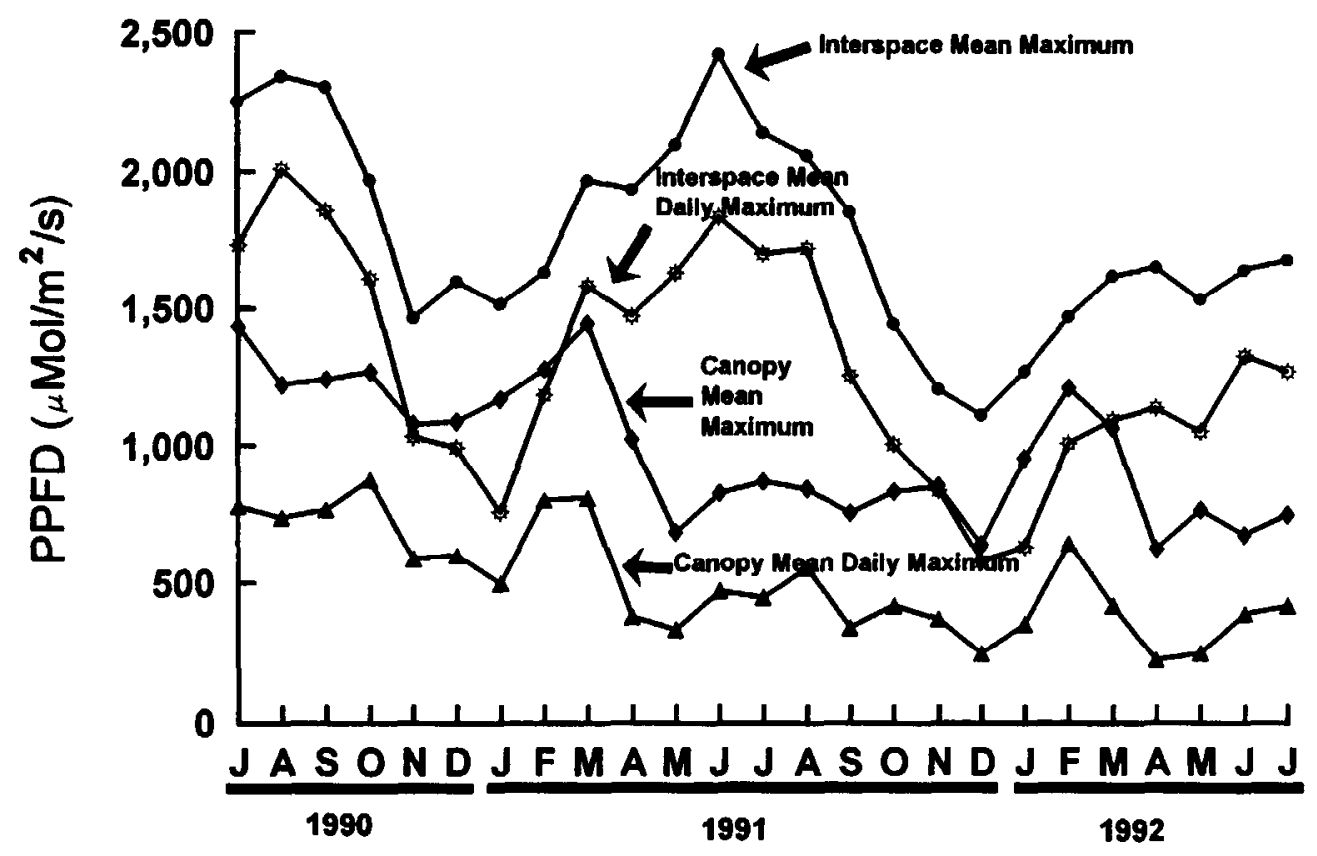

Fig. 1. Monthly trends in mean daily maximum and mean maximum photosynthetic photon flux density (PPFD) $15 \mathrm{~cm}$ above the soil surface under Prosopis glandulosa canopies and in interspaces $(n=4)$ dominated by herbaceous vegetation, Texas A\&M University-Kingsville Range and Wildife Research Area, Kleberg County, Texas, July 1990 - July 1992. 
test in this study include greater soil nutrients and soil water beneath mesquite, amelioration of soil temperatures by mesquite canopies, and differential dissemination of seeds. Franco-Pizaña et al. (1996) rejected the hypotheses that greater soil nutrients and greater soil water beneath mesquite facilitate establishment of spiny hackberry. However, amelioration of soil temperatures by mesquite canopies is a possible factor in spiny hackberry establishment. Fulbright et al. (1995) found that soil surface temperature $\left(45-50^{\circ} \mathrm{C}\right)$ beneath mesquite canopies during summer reduce seed dormancy, possibly by accelerating after ripening. In addition, honey mesquite appears to provide a perching structure for birds and serves as a focal point for seed dispersal by birds consuming spiny hackberry fruits (Archer 1995). Based on these results and those of the current study, occurrence of spiny hackberry beneath mesquite appears to result from mesquite canopy effects on soil temperatures and differential seed dissemination rather than from spiny hackberry functioning as a sciophyte.

Huisache seedling growth was also reduced by shade. Low irradiance may inhibit growth of huisache and spiny hackberty by reducing NAR. Patterson et al. (1978) also reported a positive correlation between NAR and $\mathrm{K}_{\mathrm{w}}$ in cotton (Gossypium hirsutum L.) and 3 weed species. In their study, low irradiance depressed $K_{w}$ and NAR but caused a simultaneous increase in LAP and the amount of leaf area per total amount of dry weight.

Reduced seedling growth in shade does not explain absence of huisache beneath mesquite, since seedling mortality did not occur. In contrast to spiny hackberry, huisache seeds are not dispersed by birds (Huebotter 1991). Lack of avian seed dispersal

Table 2. Means and standard errors $(n=3)$ for growth indices of spiny hackberry and huisache seedlings grown with PPFD similar to interspaces $\left(\widetilde{x}=1,893 \pm 149 \mu \mathrm{mol}^{-2} \cdot \mathrm{s}^{-1}\right)$ or PPFD similar to under honey mesquite canopies $\left(\bar{x}=569 \pm 45 \mu \mathrm{mol}^{-2} \cdot \mathrm{s}^{-1}\right)$. Values for leaf area, leaf mass, root mass, and total seedling mass are for the final harvest.

\begin{tabular}{|c|c|c|c|c|c|}
\hline Species and & & pace & & & \\
\hline seedling growth trait & $\bar{x}$ & SE & $\overline{\bar{x}}$ & SE & $P$ \\
\hline Spiny hackberry & & & & & \\
\hline $\mathrm{K}_{\mathrm{a}}\left(\mathrm{cm}^{2} \cdot \mathrm{wk}^{-1} \cdot \mathrm{cm}^{-2}\right)$ & 0.72 & 0.02 & 0.65 & 0.03 & 0.139 \\
\hline$K_{1}\left(g \cdot w k^{-1} \cdot g^{-1}\right)$ & 0.80 & 0.02 & 0.69 & 0.06 & 0.090 \\
\hline$K_{T}\left(g \cdot w k^{-1} \cdot g^{-1}\right)$ & 0.75 & 0.02 & 0.59 & 0.03 & 0.057 \\
\hline$K_{w}\left(g \cdot w k^{-1} \cdot g^{-1}\right)$ & 0.83 & 0.01 & 0.68 & 0.05 & 0.074 \\
\hline LAP $\left(\mathrm{cm}^{2} \cdot \mathrm{wk}^{-1} \cdot \mathrm{g} \cdot \mathrm{wk}\right)$ & 92 & 0.5 & 158 & 6.8 & 0.011 \\
\hline $\operatorname{LMP}\left(g \cdot w^{-1} \cdot g^{-1} \cdot w k\right)$ & 0.52 & 0.01 & 0.59 & 0.01 & 0.074 \\
\hline NAR $\left(\mathrm{mg} \cdot \mathrm{wk}^{-1} \cdot \mathrm{cm}^{-2}\right)$ & 7.8 & 0.1 & 4.2 & 0.4 & 0.007 \\
\hline Leaf area $\left(\mathrm{cm}^{2}\right)$ & 336 & 30 & 159 & 30 & 0.011 \\
\hline Leaf mass (g) & 2.0 & 0.2 & 0.7 & 0.1 & 0.0004 \\
\hline Root mass (g) & 1.0 & 0.03 & 0.3 & 0.01 & 0.018 \\
\hline Stem mass (g) & 1.3 & 0.07 & 0.3 & 0.09 & 0.023 \\
\hline Total seedling mass (g) & 4.3 & 0.07 & 1.2 & 0.3 & 0.006 \\
\hline Huisache & & & & & \\
\hline $\mathrm{K}_{\mathrm{a}}\left(\mathrm{cm}^{2} \cdot \mathrm{wk}^{-1} \cdot \mathrm{cm}^{-2}\right)$ & 0.53 & 0.03 & 0.55 & 0.04 & 0.666 \\
\hline$K_{1}\left(g \cdot w k^{-1} \cdot g^{-1}\right)$ & 0.64 & 0.03 & 0.55 & 0.04 & 0.107 \\
\hline $\mathrm{K}_{\mathrm{T}}\left(\mathrm{g} \cdot \mathrm{wk}^{-1} \cdot \mathrm{g}^{-1}\right)$ & 0.75 & 0.03 & 0.60 & 0.05 & 0.039 \\
\hline $\mathrm{K}_{\mathrm{w}}\left(\mathrm{g} \cdot \mathrm{w} \mathrm{k}^{-1} \cdot \mathrm{g}^{-1}\right)$ & 0.73 & 0.03 & 0.61 & 0.05 & 0.069 \\
\hline LAP $\left(\mathrm{cm}^{2} \cdot \mathrm{wk}^{-1} \cdot \mathrm{g}^{-1} \cdot \mathrm{wk}\right)$ & 44 & 1.3 & 93 & 4.8 & 0.007 \\
\hline LMP $\left(g \cdot w k^{-1} \cdot g^{-1} \cdot w k\right)$ & 0.35 & 0.004 & 0.42 & 0.003 & 0.005 \\
\hline NAR $\left(\mathrm{mg} \cdot \mathrm{wk}^{-1} \cdot \mathrm{cm}^{-2}\right)$ & 12.0 & 0.9 & 5.9 & 0.6 & 0.014 \\
\hline Leaf area $\left(\mathrm{cm}^{2}\right)$ & 223 & 17 & 255 & 27 & 0.183 \\
\hline Leaf mass (g) & 2.0 & 0.1 & 1.2 & 0.1 & 0.004 \\
\hline Root mass (g) & 2.2 & 0.05 & 0.9 & 0.05 & 0.0003 \\
\hline Stem mass (g) & 2.6 & 0.1 & 1.2 & 0.1 & 0.003 \\
\hline Total seedling mass ( $\mathrm{g}$ ) & 6.9 & 0.2 & 3.3 & 0.2 & 0.0009 \\
\hline
\end{tabular}

may be one reason the shrub does not occur beneath mesquite. However, white-tailed deer (Odocoileus virginianus) consume huisache pods (Ruthven et al. 1994), and possibly disseminate seeds beneath mesquite while browsing on spiny hackberry and other understory shrubs. Further research is needed to determine why huisache does not occur in the understory of honey mesquite because reasons for its absence are unclear.

Temperature and PPFD effects were possibly confounded in our experiment, since mean weekly maximum temperatures were greater in the sunlight treatment than in the shade treatment. However, we feel that treatment effects in our experiment primarily resulted from PPFD effects because seedling growth indices of spiny hackberry did not differ between $30-20^{\circ} \mathrm{C}(11$ hours/day at the warmer temperature) and $40-20^{\circ} \mathrm{C}$ in an experiment conducted in a plant growth chamber (Fulbright et al. 1995).

\section{Literature Cited}

Archer, S. 1995. Tree-grass dynamics in a Prosopis-thornscrub savanna parkland: reconstructing the past and predicting the future. Ecosci. 2:83-99.

Archer, S., C. Scifres, C.R. Bassham, and R. Maggio. 1988. Autogenic succession in a subtropical savanna: Conversion of grassland to thorn woodland. Ecol. Monog. 58:111-127.

Bush, J.K. and O.W. van Auken. 1986. Light requirements of Acacia smallii and Celtis laevigata in relation to secondary succession on floodplains of South Texas. Amer. Midl. Nat. 115:118-122.

Cody, R.P. and J.K. Smith. 1991. Applied statistics and the SAS Programming Language, 3rd Edition, North Holland, N.Y.

Franco-Pizaña, J., T.E. Fulbright, and D.T. Gardiner. 1995. Spatial relationships between shrubs and Prosopis glandulosa canopies. J. Veg. Sci. 6:73-78

Franco-Pizaña, J.G., T.E. Fulbright, D.T. Gardiner, and A.R. Tipton. 1996. Shrub emergence and seedling growth in microenvironments created by Prosopis glandulosa. J. Veg. Sci. 7:257-264.

Fulbright, T.E., J.O. Kuti, and A. R. Tipton. 1995. Effects of nurseplant canopy temperatures on shrub seed germination and seedling growth. Acta(Ecologica 16:621-632.

Fulbright, T.E., A.M. Wilson, and E.F. Redente. 1985. Seedling growth of green needlegrass and blue grama in controlled environments. J. Range Manage. 38:410-414.

Huebotter, N.H. 1991. Successional processes in a Texas savanna woodland: the role of birds and rodents. M.S. Thesis, Texas A\&M University, College Station, $125 \mathrm{pp}$.

Patterson, D.T., C.R. Meyer, and P.C. Quimby, Jr. 1978. Effects of irradiance on relative growth rates, net assimilation rates, and leaf area partitioning in cotton and three associated weeds. Plant Physiol. 62:14-17.

Potter, J.R. and J.W. Jones. 1977. Leaf area partitioning as an important factor in growth. Plant Phys. 59:10-14.

Ruthven, D.C., E.C. Hellgren, and S.L. Beasom. 1994. Effects of root plowing on white-tailed deer condition, population status, and diet. J. Wildl, Manage. 58:59-70.

Salisbury, F.B. and C.W. Ross. 1985. Plant physiology, 3rd edition. Wadsworth Publishing Company, Belmont, Calif. 